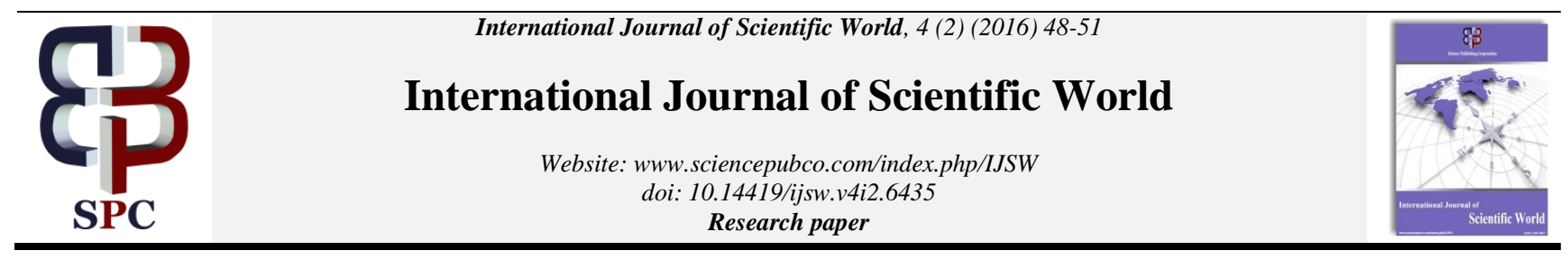

\title{
Solid state fermentation and bioconversion of ripe and unripe pineapple peels using aspergillus Niger
}

\author{
Femi-Ola *, Titilayo Olufunke, Atere, Ayowole Victor, Fapohunda, Daniel Gbenga \\ Department of Microbiology, Ekiti State University, P. M. B. 5363, Ado-Ekiti, Nigeria \\ *Corresponding author E-mail: titifemi2006@yahoo.com
}

\begin{abstract}
Pineapple peels are considered as waste in industrial and house hold setting. This research was aimed at converting these waste into useful product through bioconversion using Aspergillus niger. The proximate analysis, reducing sugar, $\mathrm{pH}$, and titratable acidity of the both ripe and unripe peels of pine apple was carried out at the onset of the fermentation and at an interval of 24 hours for 96 hours. These analyses carried out on both ripe and the unripe peels of pineapple showed that, the crude protein increased from $3.96 \%$ to $9.84 \%$ in the ripe pineapple peel and increased from $3.21 \%$ to $6.41 \%$ in unripe peels. The crude fiber reduced from $14.09 \%$ to $3.23 \%$ in the ripe pineapple peels while the crude fiber of the unripe peels reduced from 10.15 to 4.62 at the end of the 96 hour fermentation. Increase in titratable acidity, reduction in reducing sugar and $\mathrm{pH}$ was recorded for both ripe and unripe peels during the fermentation period. The optimum bioconversion was recorded at 72 hours of fermentation where the pick in the crude protein was recorded. The fat content of the pineapple peel in both ripe and unripe pineapple peel remain fairly constant throughout the fermentation period. The ripe pineapple peel yielded more protein compared to the unripe pineapple peels. This is an indication that the ripe pineapple peels are more preferred for industrial application.
\end{abstract}

Keywords: Fermentation; Peels; Waste; Aspergillus; Titratable Acidity.

\section{Introduction}

The concept of using solid substrate fermentation is probably the oldest method used by man to make microorganisms work for him [13]. Solid-state fermentation (SSF) offers greatest possibilities when fungi are used. Unlike other microorganisms, fungi typically grow in nature on solid substrates such as pieces of wood, seeds, stems, roots and dried parts of animals such as skin, bones and fecal matter which are low in moisture content [3]. The aim of SSF is to bring cultivated fungi or bacteria in tight contact with the insoluble substrate and to achieve the highest nutrient concentration from the substrate for fermentation.

Bioconversion can be described to be the use of biological processes to transform biomass materials from one form to another. Such conversions involve the use of enzymes, microbes or other biological agents, alone or in combination [12]. The utilization of fungi for nutrient enhancement in agro-industrial waste by fermentation has been studied for years and their efficiency shown in substrates such as lignin, cellulose and hemi cellulose polymers found in agro-industrial waste [9]. Aspergillus niger have been successfully used in a number of fermentation studies towards solid waste management, biomass energy conservation and production of secondary metabolites in various agro-industrial wastes [6], [10], [15].

Pineapple is a perennial monocotyledonous plant having a terminal inflorescence and a terminal multiple fruit, which exhibit high moisture content, high sugars content, soluble solid content ascorbic acid and low crude fibre. Thus pineapple can be used as supplementary nutritional fruit for good personal health [8]. However the peels are seen as waste which could be converted to a more useful product. Therefore, the aim and objective of this study was to determine the bioconversion ability of Aspergillus niger during fermentation of pineapple peels (ripe and unripe), monitor the effect of fermentation on the $\mathrm{pH}$, titratable acidity, reducing sugar and moisture content as the fermentation progressed.

\section{Materials and method}

\subsection{Pineapple}

The Pineapple used for this research was gotten from the Oja-Oba market Ado-Ekiti, Nigeria. The Aspergillus niger used was gotten from a slant of the organism which was isolated from spoiled pawpaw around Ado-Ekiti, Ekiti State. The organism was activated using Potato Dextrose agar (PDA) and allowed to grow for 5 days before use. Pure culture of Aspergillus niger on the PDA plate were scrapped off and mixed with $25 \mathrm{ml}$ of sterile PD Broth. Approximately $2 \mathrm{ml}$ of suspension was used to inoculate each of the sample.

\subsection{Processing}

The ripe and the unripe ripe pineapple were transported to the laboratory for analysis. The peel of the pineapple was blended and collected in $250 \mathrm{ml}$ conical flasks. The contents were sterilized in the autoclave at $121^{\circ} \mathrm{C}$ for 15 minutes. The samples were then cooled. Two ( $2 \mathrm{ml}$ ) of the Aspergillus niger spore suspension was used to inoculate the plates. Analyses were carried out at the onset of the fermentation, $24 \mathrm{~h}, 48 \mathrm{~h}, 72 \mathrm{~h}$ and $96 \mathrm{~h}$ to determine the proximate composition, the reducing sugar, titratable acidity and the $\mathrm{pH}$. 


\subsection{Determination of the proximate composition}

The proximate composition of the samples was determined using standard method as described by AOAC [1].

\subsection{Determination of Glucose content}

The Anthrone-sulphuric acid method was used for the determination of the glucose content of the samples [2].

\subsection{Determination of $\mathrm{pH}$}

The $\mathrm{pH}$ of the sample were determine using AOAC [1] standard One gram $(1 \mathrm{~g})$ of the sample was added to $5 \mathrm{ml}$ of distilled water mixed to form a slurry. The $\mathrm{pH}$ meter (Techmel Techmel SC 2100 Series) was standardized using buffer of $\mathrm{pH} 7$ and thereafter used in determining the $\mathrm{pH}$.

\subsection{Determination of the titratable acidity}

The slurry of the sample $(10 \% \mathrm{w} / \mathrm{v})$ was made by adding $50 \mathrm{ml}$ of distilled water to $5 \mathrm{~g}$ of the sample. The slurry was filtered through Whatman no 1 filter paper. Aliquot $(10 \mathrm{ml})$ was taken and titrated against sodium hydroxide $(0.125 \mathrm{M})$ using phenolphthalein as an indicator [1].

\section{Result}

The ash content of the ripe pineapple peels increased from 2.43 in unfermented to $4.79 \%$ at 96 hour of fermentation. The moisture content of the ripe pineapple peel increased gradually during the fermentation period from a value of $84.20 \%$ to $98.90 \%$ at the end of the 96 hour fermentation. The crude protein of the sample increased from $3.96 \%$ at $\mathrm{t}=0$ hour until a drop was observed after 72 hour of fermentation. The carbohydrate and the fat content of the fermented ripe pineapple peel showed no regular trend during the fermentation period. The crude fiber of the sample decreased from $14.09 \%$ till the end of the fermentation at 96 hour. The fat content remain fairly constant throughout the fermentation period (table 1). Table 2 showed the proximate result of the unripe pineapple peels. The ash content of the fermenting unripe pineapple peel increased from 3.41 to $4.11 \%$ at the end of the 96 hour fermentation. There was an increase in the moisture content from $76.41 \%$ at the onset of the fermentation to $86.10 \%$ at 96 hour of fermentation. The crude protein of the unripe pineapple peel also increased from 3.21 to $7.86 \%$ at 72 hour of fermentation and later dropped to $6.41 \%$ at 96 hour of fermentation. The fiber reduced throughout the fermentation period from 10.15 to $4.62 \%$ at the end of the 92 hour fermentation. The changes observed for the carbohydrates are not steady. The fat content remain fairly constant throughout the fermentation period.

Table 1: Proximate Composition of Ripe Pineapple Peel during Fermentation with Aspergillus Niger (\%)

\begin{tabular}{llllll}
\hline Constituent & 0 hour & 24 hour & 48 hour & 72 hour & 96 hour \\
\hline Ash & 2.43 & 3.23 & 4.11 & 4.18 & 4.79 \\
Moisture & 84.20 & 84.40 & 87.10 & 88.60 & 89.90 \\
Crude protein & 3.96 & 4.51 & 4.75 & 10.35 & 9.84 \\
Fat & 0.53 & 0.43 & 0.41 & 0.43 & 0.42 \\
Fiber & 14.09 & 12.30 & 10.85 & 5.62 & 3.32 \\
Carbohydrate & 76.85 & 76.83 & 80.07 & 75.35 & 76.58 \\
\hline
\end{tabular}

Table 2: Proximate Composition of Unripe Pineapple Peel during Fermen-

tation with Aspergillus Niger (\%)

\begin{tabular}{llllll}
\hline Constituent & 0 hour & 24 hour & 48 hour & 72 hour & 96 hour \\
\hline Ash & 3.41 & 3.21 & 3.40 & 4.10 & 4.11 \\
Moisture & 76.41 & 72.10 & 82.12 & 84.10 & 86.10 \\
Crude protein & 3.21 & 4.42 & 5.46 & 7.86 & 6.41 \\
Fat & 0.61 & 0.55 & 0.50 & 0.50 & 0.51 \\
Fiber & 10.15 & 7.53 & 6.34 & 5.36 & 4.62 \\
Carbohydrate & 74.80 & 75.10 & 77.90 & 75.35 & 75.90 \\
\hline
\end{tabular}

There was a sharp reduction in the reducing sugar of both ripe and unripe pineapple peels between the time of inoculation and 24 hour of fermentation from $8.2 \%$ to $2.2 \%$ and $6.2 \%$ to $2.3 \%$ respectively (Figure 1). The titratable acidity of the ripe peels increased from the onset of the fermentation till 72 hours after which there was a drop from $0.38 \% \mathrm{~m} / \mathrm{v}$ to $0.35 \% \mathrm{~m} / \mathrm{v}$ at the end of the fermentation. The $\mathrm{pH}$ of the sample reduced during the fermentation period for both samples of ripe and unripe pineapple peels (Figure 2). The initial $\mathrm{pH}$ of the ripe peel was 3.9 and gradually reduced to 3.2 at the end of the fermentation. The $\mathrm{pH}$ of the unripe pineapple peel was $3.6(0 \mathrm{~h})$ and reduced to 3.2 at 72 hour of fermentation and remain constant till the end of the fermentation (Figure 3).

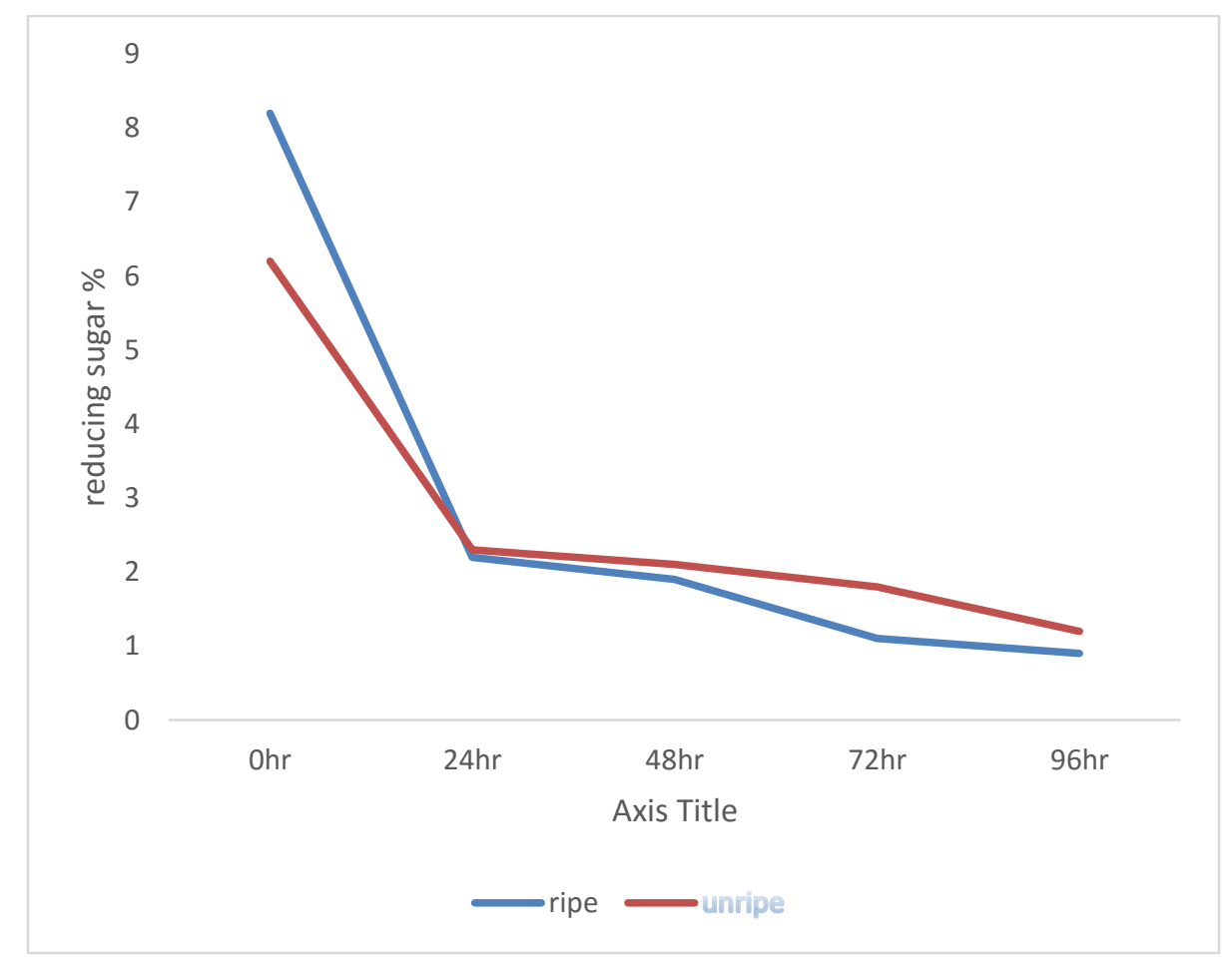

Fig. 1: Changes in the Reducing Sugar during Fermentation of Ripe and Unripe Pineapple Peels. 


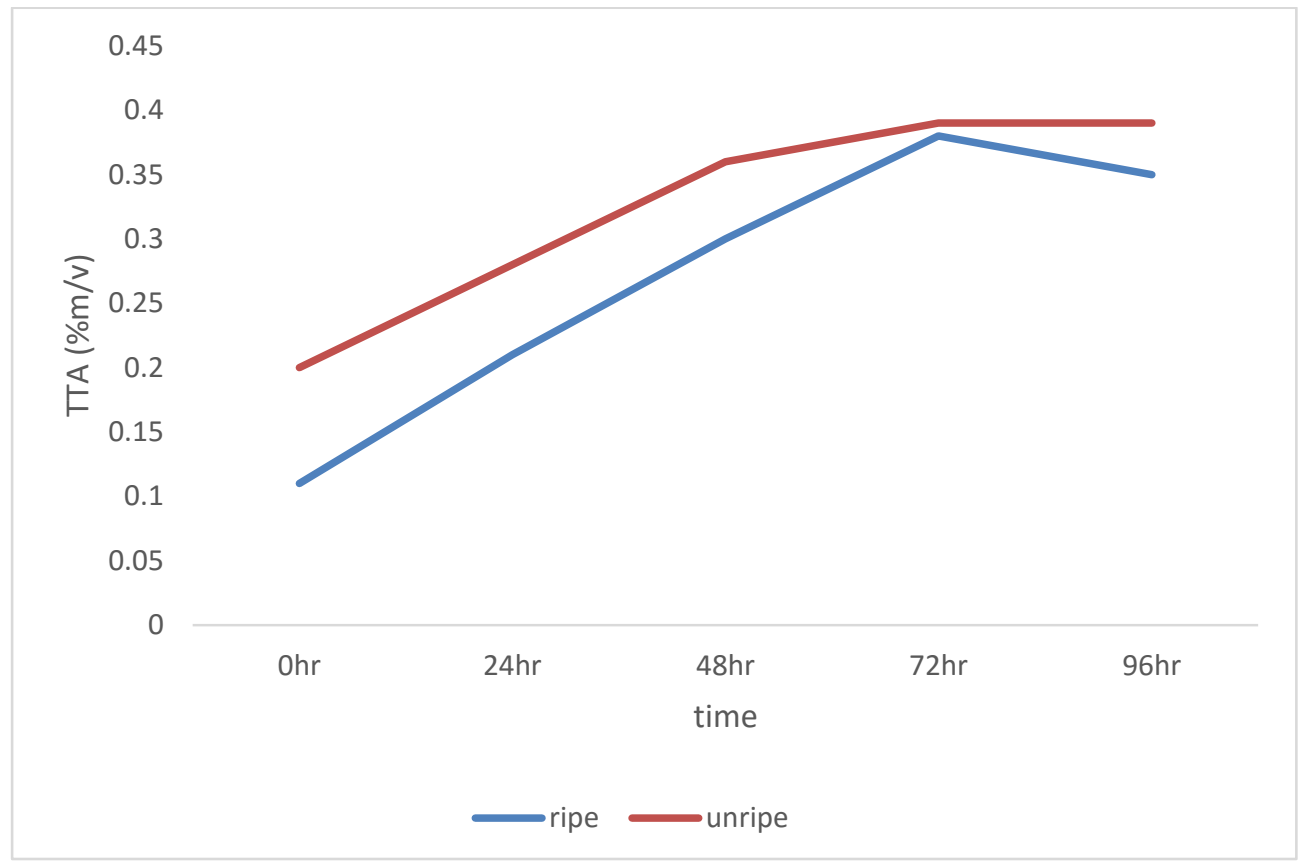

Fig. 2: The Titratable Acidity of the Fermented Ripe and Unripe Pineapple Peels.

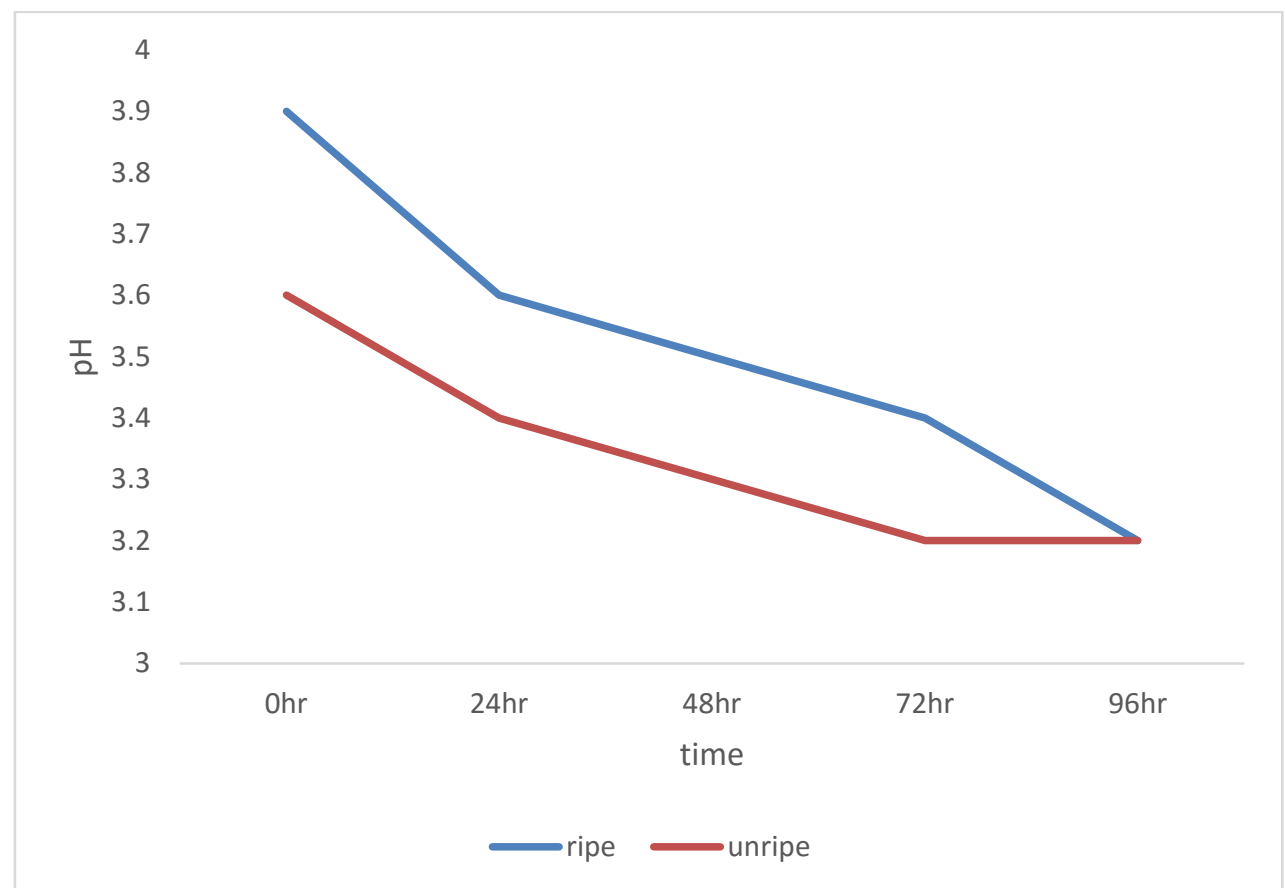

Fig. 3: Changes in the Ph of the Fermented Ripe and Unripe Pineapple Peels.

\section{Discussion}

The solid state bioconversion of peels of pineapple yielded a considerable amount of crude protein within the first 72 hours of fermentation. There was a decrease in the protein content after 72 hours of fermentation in both ripe and unripe peels, this is probably due to the proteolysis that may have occurred after 3 days of fermentation and bioprocessing [16]. In the report of Roberta et al. [16], it was also reported that there was an increase in the protein content when Saccharomyces cereviciae was used in the bioconversion of pineapple waste.

A similar trend of changes in the ash content, crude fiber and the carbohydrate of pineapple peel was reported by Evans et al. [5] where he reported an increase in the fiber content of the fermenting samples as the fermentation progressed from 0 hour till the 96 hour of the fermentation. The fermentation process in addition to enriching the substrate with protein also releases oligosaccharides and simple sugars into the medium as a result of microbial degra- dation of otherwise unavailable polysaccharides [4]. This suggests the production of hydrolytic enzymes in the fermentation culture by fungi that enable them to metabolize complex carbohydrate polymers [4], [14]. This could explain the decrease in crude fiber content. The decrease in crude fiber was noted to coincide with increase in crude protein. Other researchers have reported similar findings [4], [14]. Despite the degradation of crude fiber by the fermenting fungus, no trend in carbohydrate content in pineapple peel was recorded at 72 and $96 \mathrm{~h}$ of fermentation, this might have been the result of the fungi ability to metabolize complex sugars to simple sugars. This is attributed to the ability of fungi to further hydrolyze the simple sugars for use as a carbon source to synthesize fungal biomass rich in protein [14].

There was a sharp reduction in the reducing sugar between the inoculation and 24 hour of fermentation. This is similar to what was reported by Roberta et al. [16] who reported a sharp decrease in the reducing sugar during bioconversion of pineapple waste. The reduction in the reducing sugar is basically due to the activity of the Aspergillus niger as they proliferate [17]. Aspergillus niger 
make use of the most hydrolysable unit of sugar for the metabolism as the biomass are formed [11].

The initial $\mathrm{pH}$ of the ripe pineapple peel is higher than of the unripe, this may have been the effect of ripening on the fruit. The $\mathrm{pH}$ of the samples both ripe and unripe decreased as the fermentation progressed from 0 hour till the $96^{\text {th }}$ hour of fermentation. This may likely have been the result of accumulation of organic acid which corresponds with the increase in titratable acid of the fermenting sample. A similar result was recorded by Femi-Ola and Atere [7] during fermentation of spent grains where there was accumulation of citric acid as the fermentation progressed.

The utilization of fungi for nutrient enhancement in agro-industrial waste by fermentation has been studied for years and their efficiency shown in substrates such as lignin, cellulose and hemi cellulose polymers found in agro-industrial waste [9]. Aspergillus niger had been successfully used in a number of fermentation studies towards solid waste management, biomass energy conservation and production of secondary metabolites in various agroindustrial wastes [6], [10], [15].

\section{Conclusion}

The solid state bioconversion of the peels of pineapple revealed that the ripe pineapple peels yielded more crude protein compared to the peels of unripe pineapple. There was a decrease in the $\mathrm{pH}$ and an increase in the titratable acidity of the fermenting sample which also suggest the accumulation of organic acid. There was a considerable increase in the protein content as the peels of both ripe and unripe pineapple were fermented. The increase in the crude protein suggest that the bioconversion of the peels could serve as source of feed for animals which will meet up with the protein needed by such animals.

\section{References}

[1] A.O.A.C. (2005). Official Methods of Analysis, Association of Official Analytical Chemist. 14th edition. Washington DC. Pp. 125 219.

[2] Alben, E. and Erkmeh, O. (2004). Production of citric acid from a new substrate, undersized semolina, by Aspergillus niger. Food Technology and Biotechnology. 42 (1): 19-22.

[3] Bhargav, S., Panda, B. P. Ali, M. and Javed S. (2008). Solid-state Fermentation: An Overview Chem. Biochem. Eng. 22 (1) 49-70.

[4] Duru, C. C. and Uma, N. U. (2003). Protein enrichment of solid waste cocoyam (Xanthosoma sagittifolium (L.) Schott) cormel processing using Aspergillus oryzae obtained from cormel flour. Afr. J. Biotechnol. 2(8):228-232. http://dx.doi.org/10.5897/AJB2003.0001046.

[5] Evans, O. O., Eliud, N. M. N., George, O. O. and Ruth, N. W. (2013). Nutrient enrichment of pineapple waste using Aspergillus niger and Trichoderma viride by solid state fermentation African $\begin{array}{lll}\text { Journal of } & \text { Biotechnology (43):6193-6196. }\end{array}$ http://dx.doi.org/10.5897/AJB2013.12992.

[6] Femi-Ola, T. O., Oluyege, J. O. and Gbadebo, A. O. (2009) Citric acid production from pineapple waste. Continental Journal of $\mathrm{Mi}$ crobiology $3: 1-5$

[7] Femi-ola, T. O. and Atere, V. A. (2013). Citric acid production from brewers spent grain by Aspergillus niger and Saccharomyces cerevisiae. Inter. J. Res. Biosci. 2(1): 30- 36.

[8] Hemalatha, R. and Anbuselvi, S. (2013). Physicochemical constituents of pineapple pulp and waste. J. Chem. Pharm. Res. 5(2):240242.

[9] Howard, R. L., Abotsi, E., Jansen-van, E. L. and Howard, S. (2003). Lignocellulose biotechnology: issues of bioconversion and enzyme production. Afr. J. Biotechnol. 2(12):602-619. http://dx.doi.org/10.5897/AJB2003.000-1115.

[10] Kareem, S. O., Akpan, I. and Alebiowu, O. O. (2010). Production of citric acid by Aspergillus niger using pineapple waste. Malaysian J. Microbiol. 6(2):161-165.

[11] Kumar, J., Jain, V., Shanker, G. and Srivastava, A. (2003). Utilization of fruit waste for citric acid production by solid state fermentation, Proc Biochem, 38:1725-1729. http://dx.doi.org/10.1016/S0032-9592(02)00253-4.
[12] Linda,.L. (2010). Bioconversion and Biorefineries of the Future Lasure, Pacific Northwest National Laboratory, National Renewable Energy Laboratory. Min Zhang pp1-16

[13] Mudgett, R. E. (1986), Solid-state fermentations, In: Manual of Industrial Microbiology and Biotechnology, American Society for Microbiology, Washington DC, pp 66-83.

[14] Oboh, G. (2006). Nutrient enrichment of cassava peels using mixed culture of Saccharomyces cerevisae and Lactobacillus spp solid media fermentation techniques. Electronic J. Biotechnol. 9(1):4649. http://dx.doi.org/10.2225/vol9-issue1-fulltext-1.

[15] Omojasola, P. F., Jelani, O. P. and Ibiyemi, S. A. (2008). Cellulase production by some fungi cultured on pineapple waste. Nature and Science 6(2):64-79.

[16] Roberta, C., Margarida, M. and Gorete, M. (2007). Protein enrichment of pineapple waste with saccharomyces cerevisiae by solid state bioprocessing. J of scientific and research 66: 259-262.

[17] Shah, M., Reddy, G.., Banerjee, R., Babu, P. and Kothari, I. (2005). Microbial degradiation of banana waste undersolid state bioprocessing using two lignocellulolytic fungi (Phylosticta spp MPS-001 and Aspergillus spp. MPS-002), Proc Biochem, 40:445-451. http://dx.doi.org/10.1016/j.procbio.2004.01.020. 